\title{
ditorial
}

\section{Homenagem póstuma ao Professor Pérsio}

Extraímos do site do CNPq e reproduzimos abaixo o resumo do currículo Lattes (atualizado em 1 de Dezembro de 2011) do Prof. Dr. Pérsio de Sousa Santos, ex-Editor responsável pela revista Cerâmica. Reproduzimos também trechos do obituário escrito pelo Prof. Dr. Antonio Carlos Vieira Coelho, divulgado pela Associação Brasileira de Cerâmica.

Resumo do CV Lattes do Prof. Pérsio de Sousa Santos

"É graduado em Engenharia Química pela Escola Politécnica pela Universidade de São Paulo (1951), Mestrado em Biofísica pela University of Pittsburgh (1956), Doutorado em Engenharia Química pela Escola Politécnica da Universidade de São Paulo (1959). Pós-Doutorado(Professor visitante) na Rutgers - The State University of New Jersey (por dois períodos, em 1991 e 1992). É Professor Titular desde 1968 (atualmente aposentado), atuando no Departamento de Engenharia Metalúrgica e de Materiais da Escola Politécnica da Universidade da Universidade de São Paulo. Tem experiência na área de Química Industrial e Ciência e Tecnologia de Argilas e de Matérias-Primas Não-Metálicas. Atua principalmente nos seguintes temas: Síntese e caracterização de hidróxidos e de óxidos de alumínio e de zircônio; Aplicações industriais de argilas e de outros silicatos industriais; Valorização de argilas e outras matérias-primas minerais não metálicas brasileiras; Valorização de resíduos industriais e domésticos não-metálicos; Produção e caracterização de materiais nano-estruturados à base de argilominerais."

Obituário do Prof. Pérsio de Sousa Santos

"O ano de 2012 teve início com uma grande perda para a Escola Politécnica e para o meio científico brasileiro, com o falecimento do Prof. Dr. Pérsio de Souza Santos. Prof. Pérsio nos deixou aos quase 84 anos de idade, tendo trilhado uma carreira longa e brilhante na Escola Politécnica, onde ingressou em 1947 e se formou Engenheiro Químico em 1951. Na Poli foi professor do Departamento de Engenharia Química e do Departamento de Engenharia Metalúrgica e de Materiais. Orientou 24 Dissertações de Mestrado e 23 Teses de Doutoramento; publicou mais de 300 trabalhos científicos em revistas nacionais e internacionais, e foi um precursor no Brasil em sua área de pesquisa - Ciência e Tecnologia de Argilas, formando mais de uma geração de pesquisadores dessa área. Foi presidente da Associação Brasileira de Cerâmica por duas vezes, nos anos 1970 e 1980. Mesmo aposentado há quase 14 anos, Prof. Pérsio mantinha suas atividades de pesquisa, através de uma presença cotidiana, criativa e luminosa no Edifício Semi Industrial, no laboratório que criou e coordenou até sua aposentadoria. Jamais se furtava a uma boa conversa, nem para um desafio intelectual. A todos os que tiveram o privilégio de conhecê-lo e que tiveram o prazer do seu convívio resta a saudade e o desafio de ser dignos do seu legado."

\section{O Editor}

